Jurnal Teknologi, 46(A) Jun 2007: 43-52

(C) Universiti Teknologi Malaysia

\title{
THE ECONOMIC EVALUATION OF THE PRODUCTION OF OIL-PALM-SHELL-BASED PHENOL
}

\author{
CHUAN CHIN WONG ${ }^{1} \&$ FARID NASIR ANI ${ }^{2^{*}}$
}

\begin{abstract}
Previous work done in the extraction of phenol from oil palm shells showed that it contained up to $80.1 \%$ purity of phenolic compounds. The oil-palm-shell-based phenol is applicable to replace petroleum-based phenol in preparation of phenol formaldehyde wood adhesives. Since the average price of petroleum-based phenol is around RM 3600/ton, this work was done to estimate the cost of oil-palm-shell-based phenol. In this present research, three oil-palm-shell-based phenol manufacturing plants were investigated. Their manufacturing capacities are 1000 ton/year, 10000 ton/year, and 100000 ton/year. All the designs are based on the results from simulator DESIGN II. From the economic analysis, the cost of the oil-palm-shell-based phenol is RM 1084, RM 1008, and RM 972 per ton respectively. It shows that the cost of the oil-palm-shell-based phenol is reduced when the productivity is high. The net profit after taxes for these plants is RM 361,530, RM 4,140,764 and RM 43,943,092 per year respectively. The plants require 3 years for starting-up and their operating life is 17 years with a depreciation of $10 \%$ per year. For undiscounted cash flow, the pay back period is 10.0, 8.4, and 7.8 years respectively including the first 3 years. For different discount rates, values of net present value and discounted break-even point vary. The discounted cash flow rate of return is $14.0 \%, 20.0 \%$, and $25.0 \%$ respectively in these plants with related net present value becomes zero. The after tax rate return obtained are $71 \%, 169 \%$, and $426 \%$ respectively.
\end{abstract}

Keywords: Phenol, oil palm shells, oil-palm-shell-based phenol, petroleum-based phenol

\begin{abstract}
Abstrak. Kajian lepas yang telah dijalankan untuk mengekstrak fenol daripada tempurung kelapa sawit menunjukkan ekstrak itu mengandungi $80.1 \%$ ketulenan dan dibuktikan dapat menggantikan fenol-petroleum untuk menghasilkan resin fenol-formaldehyde. Memandangkan harga fenol adalah lebih kurang RM 3600/ton, maka pengiraan dibuat untuk menentukan harga fenol-tempurung-kelapa-sawit. Tiga jenis kilang yang berbeza akan dikaji, iaitu 1000 ton/tahun, 10000 ton/tahun, and 100000 ton/tahun. Semua pengiraan dijalankan dengan menggunakan penyelaku DESIGN II. Daripada analisis ekonomi, kos bagi ketiga-tiga kilang ialah masing-masing RM 1084, RM 1008, dan RM 972 setiap ton. Untung bersih selepas cukai ialah masing-masing RM 361,530, RM 4,140,764 dan RM 43,943,092 setiap tahun. Kilang itu memerlukan 3 tahun untuk memulakannya dan boleh beroperasi selama 17 tahun dengan penyusutan $10 \%$ setahun. Tempoh bayar balik ialah 10.0, 8.4, dan 7.8 tahun termasuk 3 tahun pertama. Peratus bayar balik selepas cukai ialah masing-masing $71 \%, 169 \%$, dan $426 \%$.
\end{abstract}

Kata kunci: Fenol, tempurung kelapa sawit, fenol-tempurung-kelapa-sawit, fenol-petroleum

1 \& 2 Department of Thermo Fluids, Faculty of Mechanical Engineering, Universiti Teknologi Malaysia, 81310 UTM Skudai, Johor, Malaysia

Corresponding author: Email: farid@fkm.utm.my 


\subsection{INTRODUCTION}

Plant design engineers are frequently confronted with the problem of estimating the manufacturing cost of a product, especially the cost of equipment. The value of equipment cost should be reasonable to the investment. In order to determine such investment accurately, it is necessary to carry out a refined design and to submit the information to manufacturers for quotations. This step is a time-consuming process. In such cases, it is sufficient to make preliminary estimates only on the sizes of various equipment items involved and to estimate the cost of such items rather than to depend on quotations [1].

In this present research, three oil-palm-shell-based phenol manufacturing plants were investigated. The plants are assumed operating 24 working hours per day and 330 working days per year. Their manufacturing capacities are 1000, 10000 , and 100000 ton/year.

All the designs are based on the results from simulator DESIGN II version 8.35. DESIGN II is a simulator program to model a specific process depending on the provided information. In this paper, only the 10000 ton/year manufacturing plant is described in detail.

\subsection{PROCESS ECONOMIC ANALYSIS}

The sizes, capacities and cost of all equipments in the simulation will be determined. The equipment sizing and costing is based on the Guthrie design method covered in reference [2]. All the calculations are based on the result from simulator DESIGN II.

Equipment sizing plays an important role in plant design. It affects the profitability of a plant where the choice of material used and the size of the units determines the feasibility of a plant. For this purpose, flow rates, temperatures, pressures and heat duties from the simulation result are needed in the calculation. Several assumptions are made on each type of the unit before sizing and costing are carried out, i.e. materials of construction, horizontal or vertical vessel, and ratio of length to diameter.

The summary of the process equipment costs for all three different production yield are shown in Table 1 . The annual production capability for these three plants will be 1000, 10000 and 100000 ton/year respectively.

The first part of economic evaluation is deciding on the exact cost of the equipment. Economic evaluation is the next step. The total of that exact cost is called a fixed capital that is the sum of capital invested on real equipment, which cannot be easily converted into another form of capital. Therefore, the Bare Module Cost (CBM) and the Total Bare Module Cost (CTBM) for the whole plant should be obtained. Bare Module method is used to estimate the cost of equipment used in the plant. All the equipment costs have been used to determine the gross roof capital (GRC) cost 
Table 1 Summary of process equipment cost in RM

\begin{tabular}{lrrr}
\hline \multicolumn{1}{c}{ Equipment } & $\mathbf{1 0 0 0}$ ton/year & $\mathbf{1 0 ~ 0 0 0}$ ton/year & $\mathbf{1 0 0} \mathbf{0 0 0}$ ton/year \\
\hline Mixer & $4,915.00$ & $20,485.00$ & $85,395.00$ \\
Extractor 1 & $16,975.00$ & $70,765.00$ & $295,020.00$ \\
Extractor 2 & $15,935.00$ & $66,375.00$ & $276,930.00$ \\
Flash separator & $8,975.00$ & $37,370.00$ & $155,785.00$ \\
Condenser & $10,645.00$ & $142,600.00$ & $636,960.00$ \\
Storage tank 1 & $33,010.00$ & $105,630.00$ & $396,105.00$ \\
Storage tank 2 & $33,010.00$ & $105,630.00$ & $396,105.00$ \\
Total CTBM, RM & $\mathbf{1 2 3 , 4 6 5 . 0 0}$ & $\mathbf{5 4 8 , 8 5 5 . 0 0}$ & $\mathbf{2 , 2 4 2 , 3 0 0 . 0 0}$ \\
\hline
\end{tabular}

for this plant. GRC makes up the major portion of total fixed capital cost (FCI). The gross-roof capital (GRC) is calculated as follows by using the formula [3]:

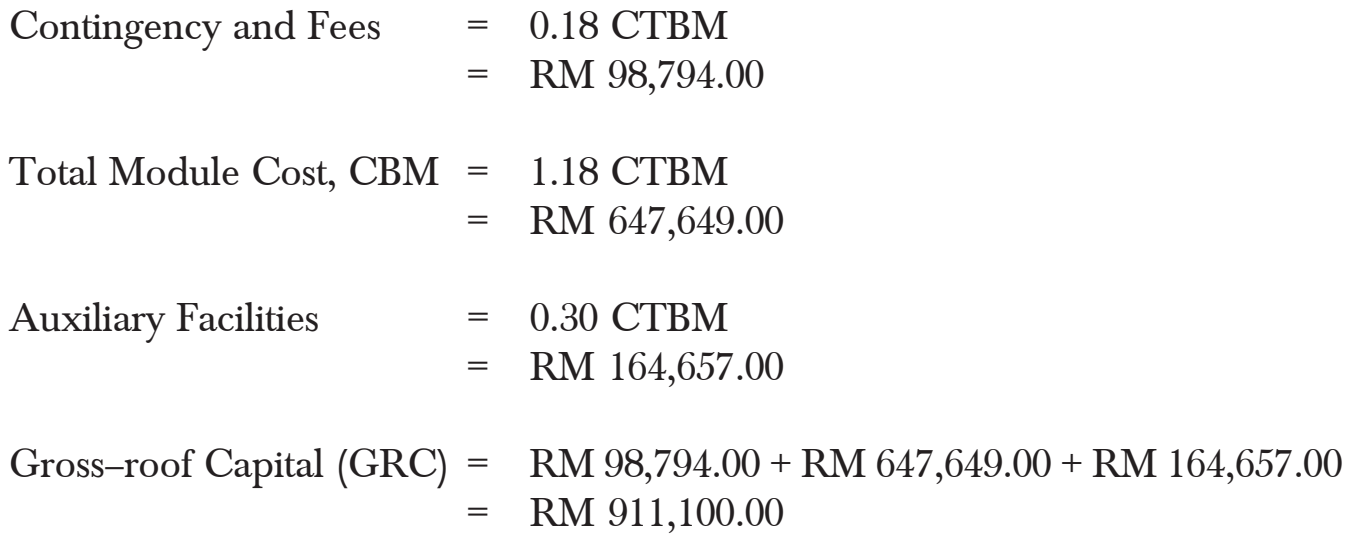

\subsection{Project Costing}

Generally, the project costing considers the total investment required for the plant full operation that is total capital cost and total production cost.

\subsubsection{Total Capital Cost}

The total capital cost includes total fixed capital and working capital costs:

(i) Total fixed capital investment:

(a) Purchased equipment cost.

(b) All items of equipment installation and construction supervision.

(c) All piping, instrumentation and control systems.

(d) Buildings and structures.

(e) Auxiliary facilities, i.e. utilities, land and civil engineering work. 
(ii) Working capital:

The additional investment needed to start-up and operate the plant to the point where income is earned. This includes the cost of:
(a) Start-up.
(b) Raw materials and intermediates in the process.
(c) Finished product inventories.
(d) Funds to cover outstanding accounts from customers.

The summary of capital cost for the 10000 ton/year production plant is shown in Table 2. The specifications are estimation methodology from reference [3].

Table 2 Estimation of fixed and total capital investment cost

\begin{tabular}{lcr}
\hline Onsite & Specification & Total (RM) \\
\hline Purchased equipment installation & $30 \% \mathrm{GRC}$ & $273,330.00$ \\
Instrumentation and control (installed) & $15 \% \mathrm{GRC}$ & $136,665.00$ \\
Piping (installed) & $40 \% \mathrm{GRC}$ & $364,440.00$ \\
Electrical and material (installed) & $8 \% \mathrm{GRC}$ & $72,888.00$ \\
Offsite & & \\
Building & $10 \% \mathrm{GRC}$ & $91,110.00$ \\
Yard improvements & $1 \% \mathrm{GRC}$ & $9,111.00$ \\
Service facilities & $5 \% \mathrm{GRC}$ & $45,555.00$ \\
Land & $2 \% \mathrm{GRC}$ & $18,222.00$ \\
TOTAL 1 & & $\mathbf{1 , 0 1} \mathbf{1 , 3 2 1 . 0 0}$ \\
Engineering and supervision & $5 \% \mathrm{GRC}$ & $45,555.00$ \\
Construction expenses & $8 \% \mathrm{GRC}$ & $72,888.00$ \\
Contractor's fee & $1.5 \% \mathrm{GRC}$ & $13,666.00$ \\
Contingency & $10 \% \mathrm{GRC}$ & $91,110.00$ \\
TOTAL 2 & & $\mathbf{2 2 3 , 2 1 9 . 0 0}$ \\
TOTAL 3 $=$ TOTAL 1 + TOTAL 2 & & $1,234,540.00$ \\
Gross Roof Capital (GRC) & TOTAL 3 + GRC & $911,100.00$ \\
Fix Capital Investment (FCI) & $12 \%$ FCI & $2,145,640.00$ \\
Working capital & $8 \%$ FCI & $257,477.00$ \\
Start up & FCI + Working & $171,651.00$ \\
Total Capital Investment, TCI & capital + Start up & $\mathbf{2 , 5 7 4 , 7 6 8 . 0 0}$ \\
& &
\end{tabular}

\subsubsection{Total Production Cost}

After determination of the total capital cost, another important part is the estimation of costs for plant operating and selling the products. These costs can be grouped under the general heading of total production cost. Generally, total production cost 
is divided into two categories, i.e. manufacturing costs and general expenses. The manufacturing cost includes direct and indirect production cost, general expenses and annual depreciation. Direct production cost includes raw material cost, utilities cost, operating labor cost, maintenance and others. The manufacturing cost of 10000 ton/year of oil-palm-shell-based phenol is shown in Table 3. The specifications are estimation methodology from reference [3]. The cost of oil-palm-shell-based pyrolysis oil is estimated as RM 304/ton [4].

Table 3 Summary of manufacturing cost

\begin{tabular}{|c|c|c|c|}
\hline Manufacturing expenses & $\begin{array}{c}\text { Consumption } \\
\text { rate }\end{array}$ & Specification & Total (RM) \\
\hline \multicolumn{4}{|l|}{ Direct production cost: } \\
\hline Pyrolysis oil & 17820 ton/year & RM 304/ton & $5,417,280.00$ \\
\hline Ethyl acetate & 4029 ton/year & RM 652/ton & $2,626,908.00$ \\
\hline Sodium bicarbonate & 891 ton/year & RM 516/ton & $459,756.00$ \\
\hline Water & $34854 \mathrm{~m}^{3} /$ year & $\mathrm{RM} 2.36 / \mathrm{m}^{3}$ & $82,255.00$ \\
\hline Cooling water & $25321 \mathrm{~m}^{3} /$ year & $\mathrm{RM} 2.36 / \mathrm{m}^{3}$ & $59,758.00$ \\
\hline Electricity & $2581250 \mathrm{kWh}$ & RM 0.23/kWh & $593,688.00$ \\
\hline Maintenance and repairs & & $3 \% \mathrm{FCI}$ & $64,370.00$ \\
\hline Operating supplies & & $0.5 \% \mathrm{FCI}$ & $10,730.00$ \\
\hline \multirow{2}{*}{ Operating labor } & & $0.0033 \times$ & \\
\hline & & $10,000,000 \times 4$ & $132,000.00$ \\
\hline \multicolumn{4}{|l|}{ Direct supervision and clerical } \\
\hline labor & & $15 \%$ operating labor & $19,800.00$ \\
\hline Laboratory charges & & $15 \%$ operating labor & $19,800.00$ \\
\hline Total 1 & & & $9,486,345.00$ \\
\hline \multicolumn{4}{|l|}{ Indirect product cost: } \\
\hline Overhead, storage & & $50 \%$ operating labor & $66,000.00$ \\
\hline Local taxes & & $1 \% \mathrm{FCI}$ & $21,456.00$ \\
\hline Insurances & & $0.5 \% \mathrm{FCI}$ & $10,728.00$ \\
\hline Total 2 & & & $98,184.00$ \\
\hline \multicolumn{4}{|l|}{ Total manufacturing } \\
\hline expenses, AME & & Total $1+$ Total 2 & $9,584,529.00$ \\
\hline \multicolumn{4}{|l|}{ General expenses: } \\
\hline Administration cost & & $10 \%$ overhead & $6,600.00$ \\
\hline Distribution and selling expenses & & $8 \%$ FCI & $171,650.00$ \\
\hline Research and development & & $5 \% \mathrm{FCI}$ & $107,280.00$ \\
\hline \multicolumn{4}{|l|}{ Total general expenses, } \\
\hline AGE & & & $285,530.00$ \\
\hline \multicolumn{4}{|l|}{ Total production cost, } \\
\hline $\mathbf{A P C}$ & & $\mathrm{AME}+\mathrm{AGE}$ & $9,870,059.00$ \\
\hline Annual depreciation, ABD & & $10 \%$ FCI & $214,564.00$ \\
\hline Total expenses, ATE & & $\mathrm{APC}+\mathrm{ABD}$ & $10,084,623.00$ \\
\hline
\end{tabular}




\subsection{Rate of Return}

The rate of return of 10000 ton/year of palm-shell-based phenol is shown as follows:

$$
\begin{aligned}
\text { Cost of extracted phenol } & =\frac{\mathrm{RM} 10,084,623.00}{10,000 \text { ton }} \\
& =\quad \mathrm{RM} 1,008 / \text { ton }
\end{aligned}
$$

As the price of petroleum-based phenol is around RM 3,600.00, the oil-palm-shellbased phenol is assumed to sell at the price of RM 1,600.00.

$\begin{array}{lll}\text { Revenue from sales } & = & \text { RM 1,600.00 × 10,000 ton / year } \\ & = & \text { RM 16,000,000.00/year } \\ \text { Annual profit } & = & \text { Revenue from sales }- \text { Total expenses } \\ & = & \text { RM 16,000,000.00 }- \text { RM 10,084,623.00 } \\ & = & \text { RM 5,915,377.00/year }\end{array}$

The income tax is assumed 30\% from the total annual profit

$\begin{array}{lll}\text { Income tax } & 0.3 \times \text { RM } 5,915,377.00 \\ & = & \text { RM 1,774,613/year }\end{array}$

Net annual profit after income tax, $\mathrm{A}_{\mathrm{NNP}}$

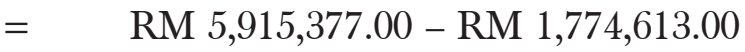

$$
\begin{aligned}
& =\mathrm{RM} 4,140,764.00 \\
& =\quad \frac{\mathrm{A}_{\mathrm{NNP}}+\mathrm{ABD}}{\mathrm{TCI}} \times 100 \% \\
& =\quad \text { Annual depreciation } \\
& =\quad \mathrm{RM} 214,564.00 \\
& \text { TCI }=\text { Total Capital Investment } \\
& =\quad \mathrm{RM} 2,574,768.00 \\
& =169 \%
\end{aligned}
$$

Rate of return$$
\text { where ABD }
$$$$
\text { Thus, rate of return }=\quad \frac{\mathrm{RM} 4,140,764.00+\mathrm{RM} 214,564.00}{\mathrm{RM} 2,574,768.00} \times 100 \%
$$

\subsection{Pay Back Period (PBP)}

Pay Back Period (PBP) is the period of time required to recover back all fixed capital investment from the start up of the plant. The plant life is estimated to be 20 years including the first 3 years of construction of the plant. The undiscounted cash flow is shown in Figure 1. From Figure 1, the pay back period for undiscounted 


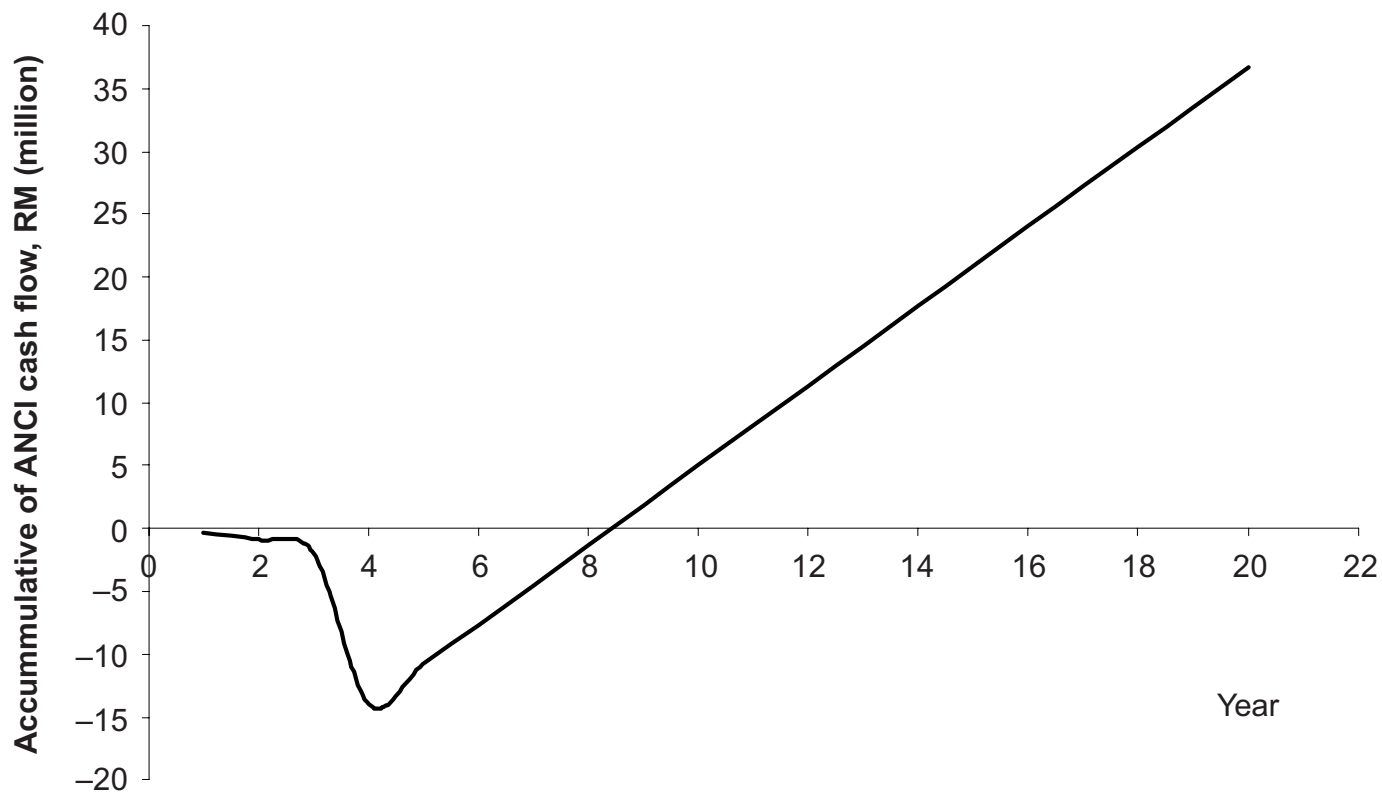

Figure 1 Cash flow for 7920 ton/year palm-shell-based phenol plant without discount rate

cash flow can be estimated as 8.4 years which includes the first 3 years set up period.

\subsection{Discounted Cash Flow Analysis}

The undiscounted cash flow analysis does not take account of time value of money. Therefore, for a more realistic analysis, the annual cash flows are multiplied by discount factors, $f_{d}$ appropriate to the year, $n$ and interest rate, $i$ in formula, which is

$$
f_{d}=\frac{1}{(1+i)^{n}}
$$

yielding a cumulative discounted cash flow in terms of current Malaysian ringgit. The result depends on the interest rate that one assumes, in which in this case, three interest rates which are $10 \%, 15 \%$ and $20 \%$ were used. The new cash flow profiles can be plotted which is shown in Figure 2.

Discounted break-even period (DBEP) can be defined as the time from the decision to process until discounted cumulative cash flow becomes positive [3]. For this case, interest rate of $10 \%$ was considered a reasonable current interest rate to assess the plant profitability. From Figure 2, the DBEP at $10 \%$ is about 10 years.

Discounted cash flow rate of return (DCFRR) is the rate of return at which a net present value (NPV) of zero is obtained at the last year of the economic study. This 


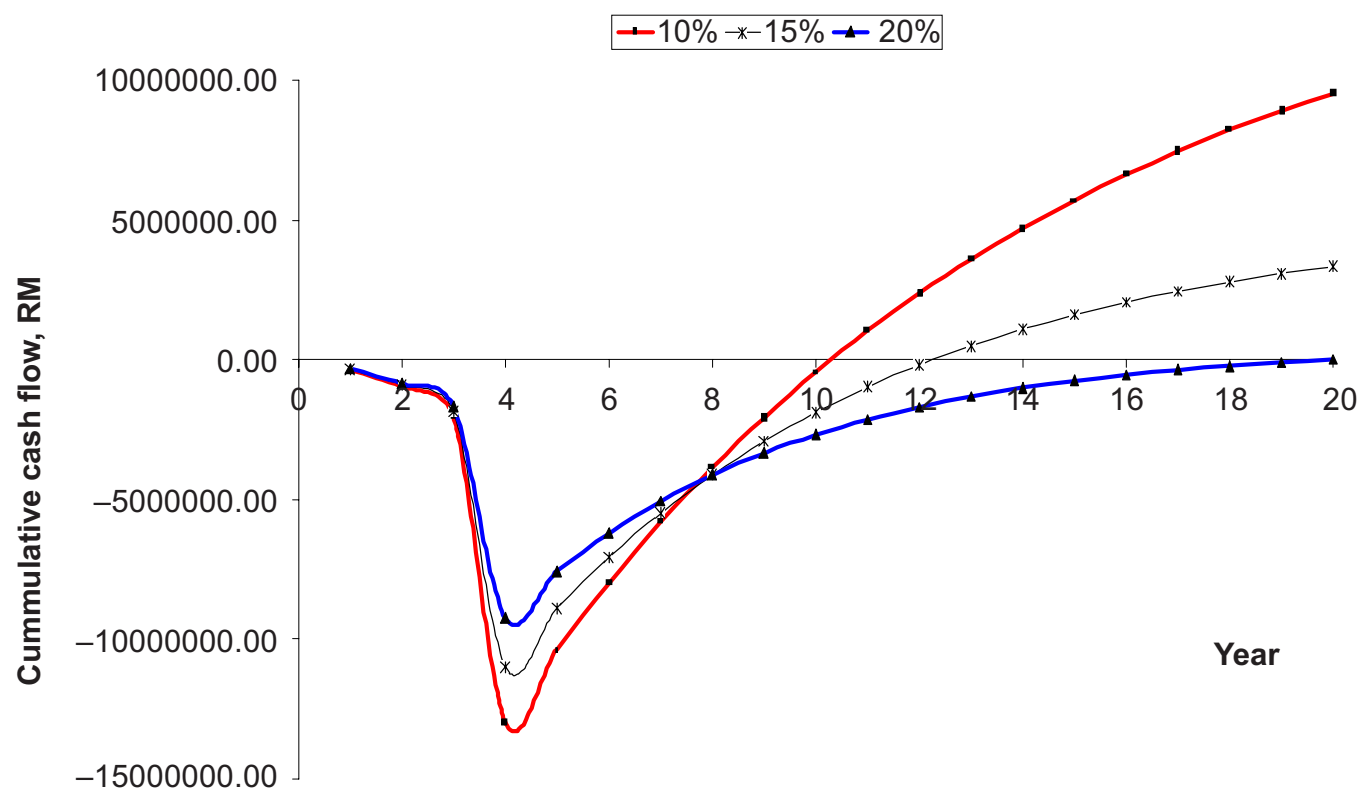

Figure 2 Cash flow for 7920 ton/year palm-shell-based phenol plant with different discount rates

value is designed to reflect the actual interest on investment. Because of this, it is useful for comparing alternate possibilities in which the DCFRR value should be higher than the interest rate available, otherwise the project is not profitable. From Figure 2, the DCFRR falls at around 20\%. This value of DCFRR is considered high compared with the current interest rate which is assumed as $10 \%$. Thus, this project is feasible due to its profitability.

\subsection{Results and Discussions}

Table 4 shows a summary of the costing results for three phenol-extraction plants. From the economic analysis, the Total Capital Investment (TCI) of these three plants are RM 579,194.00, RM 2,574,768.00 and 10,518,985.00 respectively. The annual total expenses (ATE) are RM 1,083,529.00, RM 10,084,623.00, and RM 97,224,155.00; and meanwhile, the annual revenue from sales are RM 1,600,000.00, RM 16,000,000.00, and RM 160,000,000.00 respectively. The costs of the oil-palm-shell-based phenol are RM 1,084.00, RM 1,008.00, and RM 972.00 per ton for 1000 ton/year, 10000 ton/year and 100000 ton/year productivity respectively. It shows that the cost of the oil-palm-shell-based phenol is reduced when the productivity is high. The net profits after taxes (ANNP) for these plants are RM 361,530.00, RM 4,140,764.00 and RM 43,943,092.00 per year respectively. 
Table 4 Summary of phenol extraction plant costing results

\begin{tabular}{lrrr}
\hline Specifications & $\begin{array}{c}1,000 \\
\text { ton/year }\end{array}$ & $\begin{array}{c}10,000 \\
\text { ton/year }\end{array}$ & \multicolumn{1}{c}{$\begin{array}{c}100,000 \\
\text { ton/year }\end{array}$} \\
\hline Total capital investment, TCI (RM) & $579,194.00$ & $2,574,768.00$ & $10,518,985.00$ \\
Annual total expenses, ATE (RM) & $1,083,529.00$ & $10,084,623.00$ & $97,224,155.00$ \\
Annual revenue from sales, AS (RM) & $1,600,000.00$ & $16,000,000.00$ & $160,000,000.00$ \\
Annual net profit after taxes, ANNP (RM) & $361,530.00$ & $4,140,764.00$ & $43,943,092.00$ \\
Cost of oil-palm-shell-based phenol per ton & $1,084.00$ & $1,008.00$ & 972.00 \\
(RM) & & & \\
Pay back period, PBP & 10.0 years & 8.4 years & 7.8 years \\
Discounted cash flow rate of return, DCFRR & $14.0 \%$ & $20.0 \%$ & $25.0 \%$ \\
Rate of return after taxes & $71 \%$ & $169 \%$ & $426 \%$ \\
\hline
\end{tabular}

The plants are estimated to require 3 years for starting-up and their operating life is 17 years with a depreciation of $10 \%$. For undiscounted cash flow, the pay back periods are 10.0, 8.4, and 7.8 years respectively including the first 3 years for startingup the operation of these plants. The after tax rate of return obtained are $71 \%, 169 \%$, and $426 \%$ respectively. The discounted cash flow rate of return (DCFRR) is $14.0 \%$, $20.0 \%$, and $25.0 \%$ respectively for these plants.

\subsection{CONCLUSION}

From the discounted cash flow rate of return (DCFRR), the values of $20.0 \%$ or $25.0 \%$ was determined which is high compared with the estimated current interest rate available, $10 \%$. However, the value of $14.0 \%$ is considered quite low compared with the estimated current interest rate available, 10\%. Hence, as conclusion, both of the 10000 ton/year and 100000 ton/year productivity oil-palm-shell-based extraction plant are feasible and profitable.

\section{ACKNOWLEDGEMENTS}

The authors wish to thank the Ministry of Science, Technology and Environment under IRPA Research Program for the research grant awarded (Vote no. 74060) and Universiti Teknologi Malaysia for the support to carry out this research work.

\section{LIST OF SYMBOLS}

$\begin{array}{lll}\mathrm{f}_{\mathrm{d}} & - & \text { discount factors } \\ \mathrm{n} & - & \text { number of year } \\ i & - & \text { interest rate } \\ \mathrm{C}_{\mathrm{BM}} & - & \text { bare module cost } \\ \mathrm{C}_{\mathrm{TBM}} & - & \text { total bare module cost }\end{array}$


GRC - gross roof capital

FCI - fixed capital cost

TCI - total capital investment

AME - $\quad$ total manufacturing expenses

AGE - total general expenses

APC - total production cost

ABD - - annual depreciation

ATE - - total expenses

ANP - annual net profit

ANNP - annual net profit after tax

$\mathrm{PBP} \quad$ - pay back period

DBEP - discounted break-even period

DCFRR - discounted cash flow rate of return

\section{REFERENCES}

[1] Douglas, J. M. 1988. Conceptual Design of Chemical Processes. New York: Mc Graw Hill.

[2] Coulson, J. M., J. F. Richardson, and R. K. Sinnot. 1985. Coulson \& Richardson's Chemical Engineering Volume 6: Chemical Engineering Design. $2^{\text {nd }}$ ed. London: Pergamon Press. 212-245.

[3] Ulrich, G. D. 1984. A Guide to Chemical Engineering Process Design and Economics. New York: John Wiley \& Sons. 259-402.

[4] Islam, M. N. 1999. Pyrolysis of Biomass Solid Waste and its Catalytic Treatment with Techno-Economic Analysis. Ph.D. Thesis. Universiti Teknologi Malaysia. 